\title{
The Necessity of Public Sports Infrastructure Development in Gansu Province Taking ABS Financing Mode*
}

\author{
Ying Luo ${ }^{1}$, Xiaotang $\mathrm{Li}^{2}$, Zhiliang Zeng ${ }^{3}$ \\ 1) Department of Sports Lanzhou University of Technology, GanSu, LanZhou, PRC \\ ${ }^{2)}$ Department of Sports Lanzhou University of Technology, GanSu, LanZhou, PRC \\ ${ }^{3)}$ Department of Sports Lanzhou University of Technology, GanSu, LanZhou, PRC
}

\begin{abstract}
Basic sports infrastructures are important material basis to support the sports developments. Due to the lack of construction funds, the current basic sports infrastructures in China cannot meet the growing fitness needs from citizens. The ABS financing mode is not only attract investments from overseas, but also attract domestic capital goes to the construction of basic sport infrastructures. It provides a new way for basic sports infrastructures development.

Keywords - sports infrastructure, ABS financing model, necessity

\section{甘肃省体育基础设施采用 ABS 融资模式的必要性分析}

\author{
罗英 $^{1} \quad$ 李小唐 $^{2} \quad$ 曾治良 $^{3}$ \\ 1) 兰州理工大学体育部, 兰州, 甘肃, 中国 \\ 2) 兰州理工大学体育部，兰州，甘肃，中国 \\ 3) 兰州理工大学体育部，兰州，甘肃，中国
}

摘 要 体育基础设施是体育事业发展的重要物质基础。由于建设资金缺乏，目前我国公共体育设施明显不能适应和满足广大群 众日益提高的体育运动热情及健身需求。ABS 融资模式不仅可以吸引外资, 同时也可以吸引国内资本进入基础设施建设领域, 这为 公共体育基础设施的建设发展提供了新思路。

关键词 体育基础设施，ABS 融资，必要性

\section{1. 引言}

体育基础设施是体育事业发展的重要物质基础, 是发 展竞技体育和群众体育的重要阵地, 也是推进体育产业、 体育文化建设的重要物质条件。由于体育基础设施公共品 的属性，在我国，主要依靠政府来供给，形成了投资结构 单一格局。如此单一的资金来源, 必然会阻碍体育基础设 施的有效供给, 同时给国家带来巨大的经济和社会压力。 在政府投资不足的情况下，民间资本的优势就很明显了。 这几年民间投资进行基础设施建设在我国可谓方兴未艾, 其中将民间资金转化为国家基础设施建筑资金的融资方式 被称作 $\mathrm{ABS}[1]$ 。ABS 模式不仅可以吸引外资, 同时也可以
吸引国内资本进入基础设施建设领域, 这为公共体育基础 设施的建设发展提供了新思路。

\section{2. 甘肃省体育基础设施项目融资现状}

\section{1 资金融通不流畅，投资总量不足}

甘肃省共有 14 个市州县, 经济发展程度有很大差异, 导致财政能力相差很大直接影响了各级政府对当地的体育 公共基础设施的财政资金支持力度。政府的财政拨款是现 阶段体育公共基础设施建设的重要资金来源。而现阶段甘

*甘肃省高等学校科研项目 
肃省的体育公共基础设施需要改进与新建的还有很多, 尤 其是老少边穷地区, 需要的资金数量相当可观。各市州政 府的资金支持力度差异很大, 各市居民可享受的服务质量 可就存在较大的差距。

\section{2 资金使用的效率不高}

甘肃省体育公共基础设施建设运营监管机制还不完 善, 体育公共服务部门事权、财权不对称; 体育行政部门 体育发展策略存在缺陷, 不完善的服务体系体系与不规范 的决策机制。地方政府部门的决策者利用自己现有的职位 与拥有的权力去做出体育公共产品供给决策而满足自己政 绩和利益的需要, 因此决策者往往将有限的财力用于一些 见效快, 易出政绩的短期体育基础设施的供给与建设。致 使资金的使用效率不高，体育公共基础设施的供给严重不 足, 造成供需结构失衡, 供不应求。如表一所示。
表一 中央和地方财政主要支出项目（2012 年）

\begin{tabular}{|c|c|c|}
\hline 国家财政支出 & 中央 & 地方 \\
\hline 12700.46 & 998.32 & 11702.14 \\
\hline 2268.35 & 193.56 & 2074.79 \\
\hline
\end{tabular}

\section{3 融资模式相对简单、渠道单一}

在具有中国特色的社会主义市场经济的背景下, 我国 的体育基础设施建设资金来源方式主要有政府财政拨款、 社会企业投资、提取体育彩票公益金等。筹资方式比较单 一, 比例失衡。甘肃省地处内陆, 环境闭塞, 经济欠发达, 这就导致了经济市场的不活跃, 金融工具运用的贫乏。体 育公共基础设施建设的筹资方式只能依靠政府, 但是在经 济欠发达的甘肃, 政府财政也有限。所以单一的融资方式 必定会导致体育基础设施的市场供给失灵。如图一所示, 是我国 2011 年城市公共设施投资各类资金来源的比重。

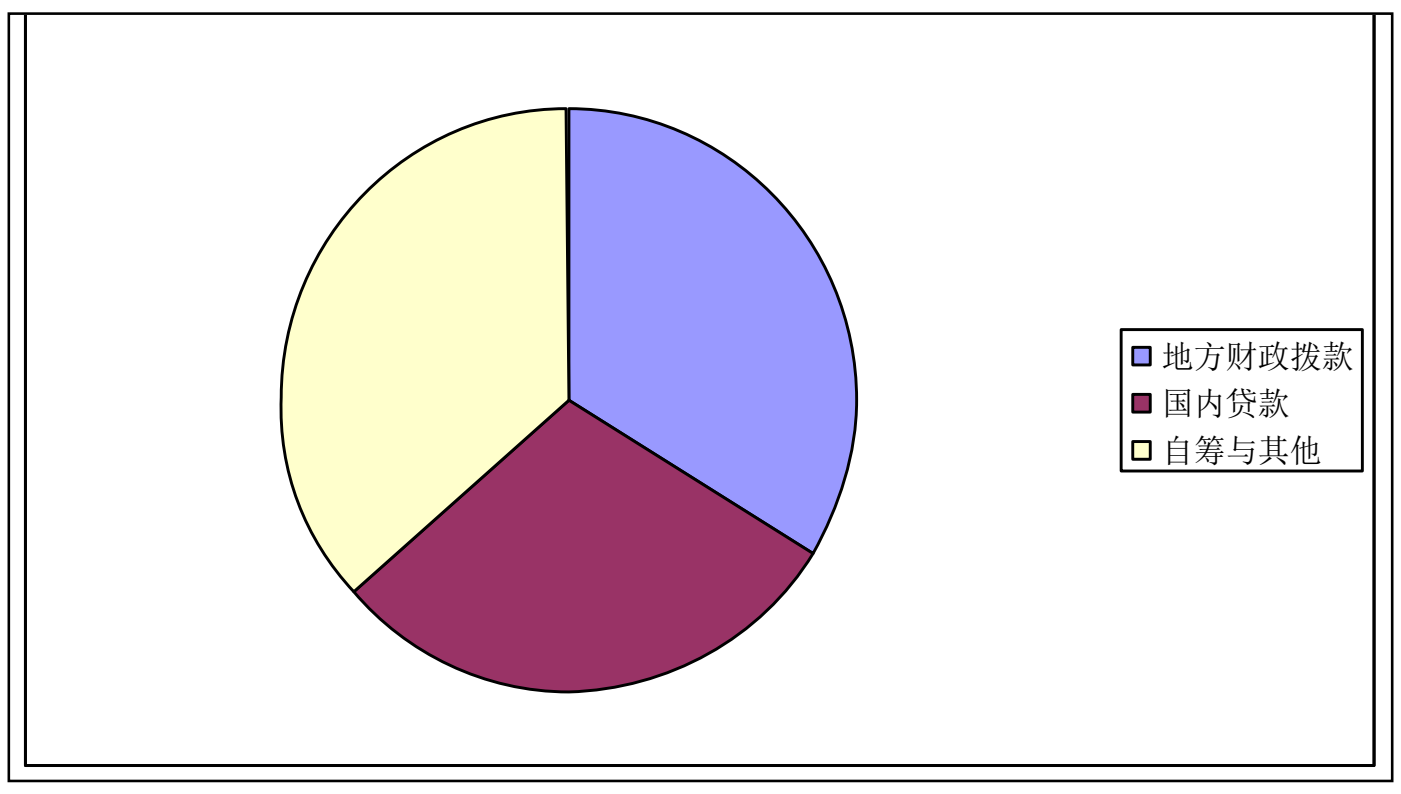

图一城市基础设施投资各资金来源的比重

资料来源: 《中国城乡建设统计年鉴 2011》 [2]

\section{3.甘肃省体育基础设施多元化融资的必要性}

社会公共体育设施是国家发展体育事业和实施全民健 身计划的主体, 是开展各类体育活动的基本条件, 也是我 国体育战略发展的最根本的物质基础。但从我国目前的情 况来看，体育基础设施建设因其投资渠道的单一、资金短 缺等诸多问题而导致其发展速度跟不上体育发展要求, 这 已逐渐成为我国体育发展的一个瓶颈。为解决体育基础设
施供给与建设资金相对短缺的矛盾多元化融资显得十分必 要。

\section{1 能够拓宽融资渠道}

多元化融资（ABS 融资）能够拓宽甘肃省体育基础设 施项目融资渠道。在我国, 公共基础设施建设资金主要来 源于中央财政或地方财政。体育基础设施隶属公共服务体 
系, 其建设基本依赖于财政拨款。所以融资方式较为单一, 渠道较窄。如果甘肃省合理利用 ABS 模式来进行体育基础 设施项目的融资, 这样不仅可以拓宽甘肃省体育基础设施 项目融资渠道, 而且为今后甘肃省体育基础设施建设的资 金筹集问题指明了方向。

\section{2 能够降低融资成本}

多元化的融资模式能够降低甘肃省体育基础设施项目 融资成本。体育基础设施建设项目的显著特点是投资额大, 建设周期长。为了节约资本, 如果能降低债息率, 就会达 到意想不到的效果一节约大量资本。然而 ABS 模式可以达 到这一目标。ABS 是通过信用增级使 ABS 发行时的信用等 级提高, 债息率一般也较低, 从而降低了项目融资成本 ${ }^{[3]}$ 。 而且 ABS 融资项目是不需要政府的特许及外汇担保, 涉及 机构较少, 酬金、差价等中间费用也较少, 融资成本又可 以进一步降低。

\section{3 可以分散投资风险}

采用多元化的融资方式可以有效的分散甘肃省体育基 础设施项目的投资风险。由于运营周期较长且遵循一定规 律, 体育基础设施项目贷款期限与风险都较稳定。一般认 为, 原始权益人向 SPV 让度资产, 构成 “真实销售”, 这样 就隔断了项目原始权益人自身风险与项目本身风险之间的 联系, 实现了 “破产隔离” ${ }^{[4]}$ 。即为了保会投资者的利益, 证券化的资产, 在发起人或原始权益人破产时, 不作为清 算财产。再者债券购买方人数众多, 这就大大分散了 ABS 投资风险。与此同时, 原始权益人通过出让资产, 预先获 取转让收入, 转移资产的所有权, 有效降低自身面临的风 险。

\section{4 可以实现一定的会计效果}

采用多元化的融资方式能够实现一定的会计效果。由 于 ABS 证券化的资产是一种 “真实销售”, 所以资产出售后 即可以从资产负债表中剔除, 从而实现表外融资 ${ }^{[5]}$ 。对原 始权益人来说, 虽然放弃资产会放弃部分收益, 但却使得 可用资金增加, 提高了资产的流动性和盈利性, 大大加快 了基础设施的建设步伐。

\section{4. 甘肃省体育场馆项目利用 ABS 融资模式的可行性 分析}

ABS 融资模式不仅可以吸引外国资本, 同时也可以吸 引国内资本进入基础设施建设领域, 这为公共体育基础设
施的建设发展提供了新思路。甘肃省体育场馆项目利用 ABS 融资模式是必要可行的。

\section{1 稳定的现金流支持及融资保证}

体育场馆的运营可以产生稳定的资金流, 为发行债券 进行融资提供了支持, 也保证了债券的还本付息。其资金 流主要来源于体育赛事的门票、停车费、广告收入、冠名 权、周边土地开发权等等。目前国内外体育赛事的频频举 行、国民的健身热为体育场馆的经营提供了极大的发展空 间。体育场馆项目投资最大的特点是具有稳定的现金流, 能够形成证券化资产的有效供给。体育基础设施建设属于 公益性事业, 受到政府的大力支持, 具有风险较低、收益 较高的特点, 符合我国大众的投资心理。体育场馆项目本 身的资产属性决定了其适应 ABS 融资模式。

\section{2 风险较低, 有政府的支持}

由于运营周期较长且遵循一定规律, 体育基础设施项 目贷款期限与风险都较稳定。采用多元化的融资方式可以 有效的分散甘肃省体育基础设施项目的投资风险。公共服 务质量均等化是我国公共服务改革的目标, 然而体育基础 设施项目是关系人民健康生活的重要部分, 必定会受到政 府的高度重视, 得到政府的支持, 获得政府担保。因此也 能实现较为明确的信用等级。

\section{3 零负债威胁}

将 ABS 融资模式引入体育基础设施项目建设领域, 可 以缓解甘肃省体育基础设建设资金短缺的现状。ABS 融资 模式运用于体育基础设施建设项目，不仅增强各方风险防 范意识, 明晰项目产权, 盘活资产, 而且具有零负债威胁 (不会增加融资方的负债)。对于遭受高负债威胁的体育基 础设施项目来说无疑是福音。除此之外, 投资者对项目投 资具有自主选择权。从而优化投资决策, 提高投资效率。 政府则可通过监管证券市场, 来调控融资规模, 进而调控 投资规模。

\section{5.结语}

甘肃省体育基础设施供需不均衡, 体育基础设施建设 资金来源单一, 为解决体育基础设施供给与建设资金相对 短缺的矛盾, 采用多元化的融资方式十分必要。ABS 模式 能够拓宽甘肃省体育场馆项目融资的渠道; 降低融资成本; 分散投资风险并且能实现一定的会计效果。甘肃省体育场 馆项目具有有稳定的现金流; 风险较低, 由政府支持; 零 
负债威胁等优势。所以甘肃省体育基础设施项目采用 $\mathrm{ABS}$ 模式是必要可行的。

\section{参考文献(References)}

[1] Xia Dan. The Analysis of ABS Financing Model Build Economy, 2011, 10

[2] 《Statistical Yearbook of Chinese Urban-Rural Constection in 2011》. 2012.
[3] Huang Jia. The Study about ABS Financing Model on Infrastruction International Economic Cooperation, 2007, 07

[4] Zheng Liping. The Analysis of the Application about ABS Financing Model in Chinese Infrastruction Construction. Economic Research Journal, 2011, 02

[5] Deng Zhaohui. The Feasibility Analysis of Sports Infrastruction Construction Financing with ABS Model. Market Modernization, 2008, 1 